\title{
Effects of Genotype, Age and Their Interaction on Egg Quality in Brown-Egg Laying Hens
}

\author{
Lukáš Zita, Eva Tůmová, Ladislav Štolc \\ Department of Animal Husbandry, Faculty of Agrobilology, Food and Natural Resources, \\ Czech University of Life Sciences Prague, Czech Republic
}

Received March 28, 2008

Accepted October 1, 2008

\begin{abstract}
The experiment compared the effects of strain and age on egg quality characteristics in ISA Brown, Hisex Brown and Moravia BSL brown-egg laying hens. One hundred and eight ISA Brown hens, forty-five Hisex Brown and forty-five Moravia BSL 20 to 60 weeks old were housed in conventional cages $\left(550 \mathrm{~cm}^{2}\right.$ per hen). Feed and water were available ad libitum. Eggs were sampled at 21-day intervals, every collecting week 150 eggs per genotype in three age periods, from 20 to 26 weeks, 37 to 43 weeks and 54 to 60 weeks of age. A total of 4,050 eggs were examined. Egg quality characteristics were affected by genotype and age. Egg weight, yolk weight and percentage, Haugh Units increased with the hens' age in all genotypes, but albumen and eggshell percentage decreased, eggshell thickness and strength improved with age. The highest egg weight $(65.3 \mathrm{~g})$ and yolk quality (yolk index $45.1 \%$ ) were found in Moravia BSL at the end of the experiment. In contrast, the best albumen quality (albumen percentage 60.0) values were in Hisex Brown and the eggshell quality measurements (eggshell thickness $0.38 \mathrm{~mm}$ ) were higher in ISA Brown.

Brown-egg layers, strain, ISA Brown, Hisex Brown, Moravia BSL, age, yolk, albumen, shell quality, correlation
\end{abstract}

The monitoring of egg quality characteristics is important mainly in terms of production economy. The attention is devoted especially to eggshell quality, because cracked eggshell presents higher losses for market-egg producers. Therefore, it is very important to evaluate the egg quality characteristics and factors affecting them. The genotype is one of the most important factors, influencing not only egg weight but also other egg characteristics.

The genotype affects mainly egg weight and eggshell characteristics. Several studies have shown heavier eggs in brown hens than in white ones (Halaj and Grofík 1994; Arent et al. 1997; Heil and Hartmann 1997; Ledvinka et al. 2000; Leyendecker et al. 2001a; Vits et al. 2005). Baumgartner et al. (2007) reported a significant effect of age on egg weight in the Leghorn type hens. Egg weight influences the weight of its components as well. The correlations between the egg weight and the albumen weight, yolk weight, eggshell weight are high and range from 0.67 to 0.97 (Zhang et al. 2005). Harms et al. (1990) reported the range of correlation between egg size and eggshell thickness as 0.920.97. The egg shape index can also be affected by the genotype (Tůmová et al. 2007). Egg shape index in the white hens Shaver Starcross 288 was higher than in the brown Moravia SSL (Halaj and Grofík 1994).

The effect of strain on yolk and albumen quality characteristics was observed by Tůmová et al. (1993). They found significantly higher yolk weight and percentage in Hisex Brown in brown eggs than in D-29 with white eggs. In contrast, Leyendecker et al. (2001b) showed significantly higher yolk weight in white egg chickens (Lohmann LSL) in comparison with the brown Lohmann Tradition. Heritability of the yolk weight is 0.45 (Zhang et al. 2005), 0.22 (Hartmann et al. 2000). From albumen quality characteristics only Haugh Units were influenced by genotype (Tůmová et al. 2007). Leyendecker et al. (2001b) found 
significantly higher value for Haugh Units in white layers than in brown hens. Zhang et al. (2005) showed that heritability of Haugh Units is 0.41 and for albumen weight 0.59 . However, Hartmann et al. (2000) found 0.41 for albumen weight. The genetic correlation between yolk percentage and yolk weight was 0.52 , whereas the genetic correlations with egg weight and albumen weight were -0.51 and -0.74 , respectively (Hartmann et al. 2000). With higher egg weight, the average albumen percentage increased (Arent et al. 1997). The genotype significantly affected the yolk index (Tůmová et al. 2007).

The eggshell quality is given through its weight and percentage of the eggshell, thickness and strength. The main differences in eggshell quality depend on the way of breeding, strain or pure lines (Buss and Guyer 1982). Egg weight directly affects the egg size and shell thickness. For instance brown hens D 102 had a higher shell weight in comparison with lines of White Leghorn (Ledvinka et al. 2000). Basmacioglu and Ergul (2005) did not report a significant effect of the genotype on shell percentage and thickness. Main differences in eggshell quality were between the white and brown hens. Brown eggs had a thicker eggshell than the white ones (Ledvinka et al. 2000) but Halaj and Grofík (1994) and Leyendecker et al. (2001b) found a thinner shell in brown eggs. Eggshell deformation was $35.7 \mathrm{~mm}$ in brown eggs and $32.6 \mathrm{~mm}$ in white. Significantly higher negative correlation among eggshell deformation and eggshell strength and thickness was found in brown eggs compared to white eggs (Halaj and Grofík 1994), but on the other hand, in white eggs these correlations were only slightly negative. Non-significant differences in shell strength were determined by Tůmová et al. (2007) in variable brown strains. However, higher shell strength was revealed in white egg chicken (Halaj and Grofík 1994; Ledvinka et al. 2000). Heritability of eggshell weight is 0.64, eggshell thickness 0.34 and eggshell strength 0.24 (Zhang et al. 2005).

The age of hens is another of the factors influencing egg weight. Peebles et al. (2000), Silversides and Scott (2001), Oloyo (2003), Van den Brand et al. (2004), Rizzi and Chiericato (2005), Johnston and Gous (2007) showed that the egg weight increased with the hens' age. On the other hand, Zemková et al. (2007) demonstrated that the egg weight was not influenced significantly by age. The age of hens also increased yolk weight (Rossi and Pompei 1995; Suk and Park 2001; Van den Brand et al. 2004), albumen weight (Rossi and Pompei 1995; Suk and Park 2001) and yolk proportion (Rossi and Pompei 1995; Rizzi and Chiericato 2005), but decreased albumen percentage (Van den Brand et al. 2004; Rizzi and Chiericato 2005). The age of hens influenced the eggshell quality (Silversides and Scott 2001; Campo et al. 2007) which deteriorated with advancing age of hens. On the other hand, Yannakopoulos and Tserveni-Gousi (1987) observed that the eggshell was thicker with hens' age, while Yannakopoulos et al. (1994) found no significant effect of the age of hens on eggshell characteristics. No effect of age on eggshell thickness was found by Van den Brand et al. (2004) and the shape index of the eggs decreased with age. The eggshell traits may be affected by interactions of age and breed (Campo et al. 2007).

The objective of this study was to determine the effect of strain and age on egg quality measurements and any possible interaction between these effects.

\section{Materials and Methods}

Animals, design and analyses

The monitoring was carried out on 198 brown-egg laying hens divided into 3 groups depending on genotype group 1 was ISA Brown (108 hens), group 2 Hisex Brown ( 45 hens) and group 3 Moravia BSL (45 hens). Moravia BSL is a three-strain hybrid of the black colour bred in the Czech Republic. The advantage of this genotype is its remarkable vitality and resistance. The live weight at the age of 18 weeks was 1,650 $\mathrm{g}$ and at the end of the laying period 2,200 g. The egg production per housed hen was 290 eggs with the average egg weight of $60.7 \mathrm{~g}$.

Hens were housed in a three-floor Big Dutchman Eurovent cages ( 3 hens per cage $-550 \mathrm{~cm}^{2}$ per hen) at the age of 15 weeks. Hens were divided into cages randomly with the same number of hens on each floor for each genotype. The experiment was conducted at the age of 20-60 weeks. Hens at the age between the $20^{\text {th }}$ and $40^{\text {th }}$ 
weeks were fed a commercial feed mixture N1 with $11.40 \mathrm{MJ}$ ME and 16.7\% of crude protein. In the following period (between the $41^{\text {th }}$ and $60^{\text {th }}$ weeks of age) the hens were fed a mixture N2 with $11.48 \mathrm{MJ}$ ME and $15.4 \%$ of crude protein. The feed and water were available ad libitum. The lighting regime consisted of $16 \mathrm{~h}$ of light and $8 \mathrm{~h}$ of darkness.

Eggs for analyses were sampled in three different parts of the laying period (from 20 to 26 weeks, from 37 to 43 weeks, from 54 to 60 weeks of age). In each period, 150 eggs from each group were sampled at a 21-day interval. In total, 4,050 eggs were examined. The egg weight, yolk, albumen and shell after drying, the shape index of the egg, yolk and albumen, percentage of yolk, albumen and eggshell were determined. The albumen height and Haugh Units were determined by QCH and QCM + device (TSS England). Deformation of the eggshell and its strength were evaluated using the QC-SPA device (TSS England). Shell thickness was measured by the QCT device (TSS England) and shell colour by the QCR device (TSS England).

\section{Statistical analyses}

The statistical analysis of the data on egg quality characteristics was performed by two-way analysis of variance, including the genotype and age and their interaction, using the GLM procedure of SAS (SAS Institute Inc., 2003). Correlations between egg quality characteristics were determined according to the PROC CORR procedure of SAS by Pearson correlation coefficients (SAS Institute Inc. 2003).

\section{Results and Discussion}

The egg weight increased with the layer's age in all genotypes (Table 1). These results are in agreement with Peebles et al. (2000), Silversides and Scott (2001), Oloyo (2003), Van den Brand et al. (2004), Rizzi and Chiericato (2005), Baumgartner et al. (2007), Johnston and Gous (2007) who showed that egg weight increases with the age of hens.

Table 1 . The effect of genotype and age on egg and yolk quality

\begin{tabular}{|c|c|c|c|c|c|c|c|}
\hline \multirow[b]{2}{*}{ Characteristic } & \multirow[b]{2}{*}{ Genotype } & \multicolumn{3}{|c|}{ Week of laying } & \multicolumn{3}{|c|}{ Significance } \\
\hline & & $20-26$ & $36-42$ & $54-60$ & $\begin{array}{l}0 \\
\text { ¿ें } \\
0 \\
0 \\
0 \\
0\end{array}$ & $\underset{8}{8}$ & 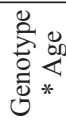 \\
\hline \multirow{3}{*}{ Egg weight $(g)$} & ISA Brown & 54.00 & 62.78 & 63.42 & \multirow{3}{*}{$* *$} & \multirow{3}{*}{$* * *$} & \multirow{3}{*}{$* * *$} \\
\hline & Hisex Brown & 54.99 & 62.11 & 64.12 & & & \\
\hline & Moravia BSL & 51.10 & 61.61 & 65.30 & & & \\
\hline \multirow{3}{*}{ Egg shape index $(\%)$} & ISA Brown & 78.52 & 76.64 & 75.09 & \multirow{3}{*}{$* * *$} & \multirow{3}{*}{$* * *$} & \multirow{3}{*}{$* * *$} \\
\hline & Hisex Brown & 78.94 & 76.88 & 75.34 & & & \\
\hline & Moravia BSL & 78.76 & 76.59 & 76.59 & & & \\
\hline \multirow{3}{*}{ Yolk weight (g) } & ISA Brown & 12.46 & 16.86 & 17.81 & \multirow{3}{*}{$* * *$} & \multirow{3}{*}{$* * *$} & \multirow{3}{*}{$* * *$} \\
\hline & Hisex Brown & 12.94 & 16.70 & 17.78 & & & \\
\hline & Moravia BSL & 11.94 & 17.96 & 19.64 & & & \\
\hline \multirow{3}{*}{ Yolk (\%) } & ISA Brown & 23.12 & 26.94 & 28.12 & \multirow{3}{*}{$* * *$} & \multirow{3}{*}{$* * *$} & \multirow{3}{*}{$* * *$} \\
\hline & Hisex Brown & 23.53 & 26.93 & 27.76 & & & \\
\hline & Moravia BSL & 23.42 & 29.23 & 30.13 & & & \\
\hline \multirow{3}{*}{ Yolk index $(\%)$} & ISA Brown & 48.12 & 44.36 & 43.63 & \multirow{3}{*}{$* * *$} & \multirow{3}{*}{$* * *$} & \multirow{3}{*}{$*$} \\
\hline & Hisex Brown & 47.22 & 43.93 & 42.91 & & & \\
\hline & Moravia BSL & 48.19 & 46.56 & 45.12 & & & \\
\hline
\end{tabular}

$* * * P \leq 0.0001 ; * * P \leq 0.001 ; * P \leq 0.05$

Several interactions between the genotype and hen's age were found. The Hisex Brown and ISA Brown had a significantly $(P \leq 0.001)$ higher egg weight $(55.0 \mathrm{vs} .54 .0 \mathrm{~g})$ than the 
Table 2. The effect of genotype and age on albumen quality

\begin{tabular}{|c|c|c|c|c|c|c|c|}
\hline \multirow[b]{2}{*}{ Characteristic } & \multirow[b]{2}{*}{ Genotype } & \multicolumn{3}{|c|}{ Week of laying } & \multicolumn{3}{|c|}{ Significance } \\
\hline & & $20-26$ & $36-42$ & $54-60$ & 总 & $\stackrel{80}{4}$ & 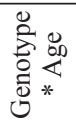 \\
\hline \multirow{3}{*}{$\begin{array}{l}\text { Albumen } \\
\text { weight (g) }\end{array}$} & ISA Brown & 34.36 & 38.07 & 37.57 & \multirow{3}{*}{$* * *$} & \multirow{3}{*}{$* * *$} & \multirow{3}{*}{$* * *$} \\
\hline & Hisex Brown & 35.28 & 37.87 & 38.49 & & & \\
\hline & Moravia BSL & 32.78 & 36.62 & 38.25 & & & \\
\hline \multirow{3}{*}{$\begin{array}{l}\text { Albumen } \\
(\%)\end{array}$} & ISA Brown & 63.85 & 60.53 & 59.19 & \multirow{3}{*}{$* * *$} & \multirow{3}{*}{$* * *$} & \multirow{3}{*}{$* * *$} \\
\hline & Hisex Brown & 64.15 & 60.92 & 59.98 & & & \\
\hline & Moravia BSL & 64.57 & 59.36 & 58.50 & & & \\
\hline & & & & & & & \\
\hline \multirow{3}{*}{$\begin{array}{l}\text { Albumen index } \\
(\%)\end{array}$} & ISA Brown & 11.27 & 8.74 & 7.46 & \multirow{3}{*}{ NS } & \multirow{3}{*}{$* * *$} & \multirow{3}{*}{$* * *$} \\
\hline & Hisex Brown & 11.33 & 9.03 & 7.11 & & & \\
\hline & Moravia BSL & 10.53 & 9.27 & 8.40 & & & \\
\hline \multirow{3}{*}{ Haugh Units } & ISA Brown & 90.34 & 81.34 & 80.02 & \multirow{3}{*}{$* * *$} & \multirow{3}{*}{$* * *$} & \multirow{3}{*}{$* * *$} \\
\hline & Hisex Brown & 90.08 & 92.76 & 83.46 & & & \\
\hline & Moravia BSL & 88.22 & 90.07 & 85.96 & & & \\
\hline
\end{tabular}

$* * * P \leq 0.0001 ; \mathrm{NS}-$ non-significant

Moravia BSL (51.1 g) at the beginning of the experiment, but at the end of the experiment Moravia BSL produced the heaviest eggs (65.3 g).

The quality of yolk is given by yolk weight and its percentage. Both of these variables increased with age in all genotypes. The highest $(P \leq 0.0001)$ yolk percentage was at the age 36 to 42 weeks and 52 to 60 weeks of age in Moravia BSL (29.23 and 30.13\%, respectively) in comparison with eggs of Hisex Brown (26.93 and 27.76\%, respectively) and ISA Brown (26.94 and 28.12\%, respectively). Rossi and Pompei (1995), Suk and Park (2001), Van den Brand et al. (2004), Tůmová and Ledvinka (2009) confirmed that the yolk weight and yolk percentage (Rossi and Pompei 1995; Rizzi and Chiericato 2005) significantly increased with the hens' age, which is in agreement with our result.

Highly significant interactions $(P \leq 0.0001)$ were also seen in all albumen quality characteristics: albumen weight, albumen percentage, albumen index and Haugh Units. As egg weight increased with the age of hens, so did the albumen weight, which is in agreement with Rossi and Pompei (1995), Suk and Park (2001). The albumen percentage decreased with the hens' age and it corresponds with the studies of Van den Brand et al. (2004) and Rizzi and Chiericato (2005), who stated that the albumen percentage decreased with age. On contrary, values of Haugh Units increased with the age of hens and were significantly affected by the genotype. The highest values in the first period were determined in ISA Brown eggs (90.3), but in the third period these values were the lowest (80.0).

The data in Table 3 show significant differences in eggshell quality. Interaction between genotype and age of hens was found in all eggshell quality characteristics. Eggshell percentage decreased with age of hens in all genotypes. Significantly $(P \leq$ 0.001 ) the highest eggshell percentage was in ISA Brown eggs in all periods of the experiment. Basmacioglu and Ergul (2005) described a non-significant effect of the genotype on shell percentage. In our study, as eggshell percentage increased, thickness and strength improved in all genotypes. The eggs of ISA Brown had a thicker eggshell than the other genotypes. Yannakopoulos and Tserveni-Gousi (1987) observed that 
Table 3. The effect of genotype and age on eggshell quality

\begin{tabular}{|c|c|c|c|c|c|c|c|}
\hline \multirow[b]{2}{*}{ Characteristic } & \multirow[b]{2}{*}{ Genotype } & \multicolumn{3}{|c|}{ Week of laying } & \multicolumn{3}{|c|}{ Significance } \\
\hline & & $20-26$ & $36-42$ & $54-60$ & $\sum_{0}^{0}$ & $\stackrel{8}{8}$ & 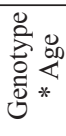 \\
\hline \multirow{3}{*}{$\begin{array}{l}\text { Eggshell } \\
\text { weight (g) }\end{array}$} & ISA Brown & 5.86 & 6.65 & 6.64 & \multirow{3}{*}{$* * *$} & \multirow{3}{*}{$* * *$} & \multirow{3}{*}{ * } \\
\hline & Hisex Brown & 5.57 & 6.27 & 6.38 & & & \\
\hline & Moravia BSL & 4.92 & 5.80 & 5.88 & & & \\
\hline \multirow{3}{*}{$\begin{array}{l}\text { Eggshell } \\
(\%)\end{array}$} & ISA Brown & 13.03 & 12.53 & 12.69 & \multirow{3}{*}{$* * *$} & \multirow{3}{*}{$* * *$} & \multirow{3}{*}{$* *$} \\
\hline & Hisex Brown & 12.32 & 12.15 & 12.26 & & & \\
\hline & Moravia BSL & 12.01 & 11.42 & 11.36 & & & \\
\hline \multirow{3}{*}{$\begin{array}{l}\text { Eggshell } \\
\text { thickness (mm) }\end{array}$} & ISA Brown & 0.37 & 0.38 & 0.38 & \multirow{3}{*}{$* * *$} & \multirow{3}{*}{$* * *$} & \multirow{3}{*}{$*$} \\
\hline & Hisex Brown & 0.35 & 0.36 & 0.36 & & & \\
\hline & Moravia BSL & 0.32 & 0.33 & 0.32 & & & \\
\hline \multirow{3}{*}{$\begin{array}{l}\text { Eggshell } \\
\text { deformation } \\
(\mathrm{mm})\end{array}$} & ISA Brown & 0.35 & 0.34 & 0.33 & \multirow{3}{*}{$* *$} & \multirow{3}{*}{$* *$} & \multirow{3}{*}{$*$} \\
\hline & Hisex Brown & 0.35 & 0.38 & 0.35 & & & \\
\hline & Moravia BSL & 0.34 & 0.36 & 0.35 & & & \\
\hline \multirow{3}{*}{$\begin{array}{l}\text { Eggshell } \\
\text { strength } \\
(\text { g.cm } \\
\end{array}$} & ISA Brown & 4892.39 & 4852.53 & 4525.23 & \multirow{3}{*}{$* * *$} & \multirow{3}{*}{$* * *$} & \multirow{3}{*}{$*$} \\
\hline & Hisex Brown & 4808.09 & 5100.79 & 4614.11 & & & \\
\hline & Moravia BSL & 4271.58 & 4510.50 & 4396.45 & & & \\
\hline \multirow{3}{*}{$\begin{array}{l}\text { Eggshell } \\
\text { colour (\%) }\end{array}$} & ISA Brown & 31.29 & 34.24 & 35.40 & \multirow{3}{*}{$* * *$} & \multirow{3}{*}{$* * *$} & \multirow{3}{*}{$* * *$} \\
\hline & Hisex Brown & 29.30 & 29.74 & 31.66 & & & \\
\hline & Moravia BSL & 45.89 & 46.11 & 48.49 & & & \\
\hline
\end{tabular}

$* * * P \leq 0.0001 ; * * P \leq 0.001 ; * P \leq 0.05$

the eggshell thickened with the hens' age, which is in agreement with our results. On the other hand, Yannakopoulos et al. (1994) found no significant effect of the age of

Table 4. Correlations between egg weight, eggshell percentage, eggshell colour and selected egg quality characteristics

\begin{tabular}{|l|c|c|}
\hline Characteristic & Characteristic & Significance \\
\hline Eggshell strength & Egg weight & \\
\hline Eggshell thickness & -0.100 & $* * *$ \\
\hline Yolk percentage & 0.152 & $* * *$ \\
\hline Albumen percentage & 0.182 & $* * *$ \\
\hline Eggshell percentage & -0.039 & $*$ \\
\hline & -0.400 & $* * *$ \\
\hline Eggshell strength & Eggshell percentage & $* * *$ \\
\hline Eggshell thickness & 0.240 & $* * *$ \\
\hline & 0.550 & $\mathrm{NS}$ \\
\hline Eggshell strength & Eggshell colour & $* * *$ \\
\hline Eggshell thickness & -0.026 & $* * *$ \\
\hline Eggshell percentage & 0.152 & -0.108 \\
\hline
\end{tabular}

$* * * P \leq 0.0001 ; * P \leq 0.05$; NS - non-significant hen on eggshell characteristics and on eggshell thickness (Van den Brand et al. 2004). The results of our experiment are in accordance with the findings of Ledvinka et al. (2000), who found a thicker eggshell in brown eggs. In contrast, Halaj and Grofík (1994) and Leyendecker et al. (2001b) found a thinner shell in brown eggs compared to the white ones. The colour intensity of the eggshell decreased with age in all genotypes. Moravia BSL had a lighter eggshell compared to Hisex Brown or ISA 
Brown. Odabasi et al. (2007), Tůmová and Ledvinka (2009) stated that eggshell pigmentation decreased with age.

Correlations between egg weight, eggshell percentage, eggshell colour and selected egg quality characteristics are presented in Table 4 . Highly significant $(P \leq 0.001)$ negative correlation between egg weight and proportion of the eggshell on the mass of the egg $(-0.400)$ was found. On the other hand, highly significant $(P \leq 0.001)$ positive correlations between eggshell percentage and thickness, strength ( 0.550 and 0.240 , respectively) were determined. Table 4 shows that the correlation coefficients of eggshell thickness with eggshell colour were positive $(0.152, P \leq 0.001)$, but that of eggshell strength and proportion with eggshell colour were negative $(-0.260$, NS and $-0.108, P \leq 0.001)$.

Egg quality characteristics were affected by the interaction of genotype and age. The highest egg weight and yolk quality were found in Moravia BSL at the end of the experiment. In contrast, the best albumen quality values were found in Hisex Brown. In addition, the eggshell quality measurements were higher in ISA Brown. The highest deviation in egg weight during the experiment was in Moravia BSL.

\section{Vliv genotypu, věku a jejich interakce na kvalitu vajec hnědovaječných slepic nosného typu}

V pokusu s hnědovaječnými nosnicemi ISA Brown, Hisex Brown a Moravia BSL byl sledován vliv genotypu a věku na kvalitu vajec. Do pokusu bylo zařazeno 108 nosnic ISA Brown, 45 Hisex Brown a 45 Moravia BSL, které byly od 20. do 60. týdne věku ustájeny v konvenčních klecích $\left(550 \mathrm{~cm}^{2} / \mathrm{ks}\right)$. Nosnice byly krmeny od 20 . do 40 . týdne věku komerčním typem krmné směsi N1 (16,4 \% N-látek; 11,6 MJ ME) a do 60. týdne věku N2 (14,9 \% N-látek; 11,6 MJ ME). Př́́jem krmiva a vody byl ad libitum. Vejce pro účely analýz byla sbírána v období od 20 . do 26 . týdne, od 37 . do 43. týdne a od 54 . do 60. týdne věku nosnic a to $\mathrm{v}$ intervalech po 21 dnech, $\mathrm{v}$ počtu $150 \mathrm{ks}$ vajec $\mathrm{v}$ daném týdnu v rámci genotypu. Celkově bylo k rozborům použito 4050 vajec. Kvalita vajec byla ovlivněna genotypem a věkem. U všech genotypů se s věkem zvyšovala hmotnost vajec, hmotnost a procentuálně podíl žloutku, Haughovy jednotky, ale snižoval se procentuální podíl bílku a skořápky, zlepšila se tloušt'ka a pevnost skořápky. Nejvyšší hmotnost vajec $(65,3 \mathrm{~g})$ a index žloutku $(45,1 \%)$ na konci experimentu byl zjištěn u genotypu Moravia BSL. Naopak, nejlepší ukazatele kvality bílku (procentuální podíl 60,0 \%) byly u genotypu Hisex Brown a ukazatele kvality skořápky (tloušt'ka $0,38 \mathrm{~mm}$ ) byly vyšší u genotypu ISA Brown.

\section{Acknowledgement}

The study was supported by Ministry of Education, Youth and Sports of the Czech Republic (Project No. MSM 6046070901).

\section{References}

Arent E, Tůmová E, Ledvinka Z, Holoubek J 1997: The effect of the plane of nutrition on egg quality in laying hens of different genotypes. Živočišná výroba 42: 427-432

Basmacioglu H, Ergul M 2005: Research on the factors affecting cholesterol content and some other characteristics of eggs in laying hens. The effect of genotype and rearing system. Turk J Vet Anim Sci 29: 157-164

Baumgartner J, Benková J, Peškovicová D 2007: Effect of line, age and individuality on yolk cholesterol content and some other egg quality traits in Leghorn type yolk cholesterol selected hens. XVIII European Symposium on the quality of poultry meat and XII European Symposium on the quality of eggs and egg products, September 2 - 5. Prague, pp. 35-36

Buss EG, Guyer RB 1982: Genetic differences in avian egg shell formation. Poult Sci 61: 2048-2055

Campo JL, Gil MG, Dávila SG 2007: Differences among white-, tinted-, and brown-egg laying hens for incidence of eggs laid on the floor and for oviposition time. Arch Geflügelkd 71: 105-109

Halaj M, Grofík R 1994: The relationship between egg shell strength and hens features. Živočišná výroba 39: 927-934

Harms RH, Rossi AF, Sloan DR, Miles RD, Christmas RB 1990: A method for estimating shell weight and correcting specific gravity for egg weight in egg shell quality studies. Poult Sci 69: 48-52 
Hartmann C, Johansson K, Strandberg E, Wilhelmson M 2000: One-generation divergent selection on large and small yolk proportions in a white Leghorn line. Br Poult Sci 41: 280-286

Heil G, Hartmann W 1997: Combined summaries of European random sample egg production tests completed in 1995 and 1996. Worlds Poult Sci J 53: 291-296

Johnston SA, Gous RM 2007: Modelling the changes in the proportions of the egg components during a laying cycle. Br Poult Sci 48: 347-353

Ledvinka Z, Tůmová E, Arent E, Holoubek J, Klesalová L 2000: Egg shell quality in some white-egg and brownegg cross combinations of dominant hens. Czech J Anim Sci 45: 285-288

Leyendecker M, Hamann H, Hartung J, Kamphues J, Ring C, Gluender G, Ahlers C, Sander I, Neumann U, Distl O 2001a: Analysis of genotype-environment interactions between layer lines and housing systems for performance traits, egg quality and bone breaking strength - $1^{\text {st }}$ communication: Performance traits. Züchtungskunde 73: 290-307

Leyendecker M, Hamann H, Hartung J, Kamphues J, Ring C, Gluender G, Ahlers C, Sander I, Neumann U, Distl O 2001b: Analysis of genotype-environment interactions between layer lines and housing systems for performance traits, egg quality and bone breaking strength $-2^{\text {nd }}$ communication: Egg quality traits. Züchtungskunde 73: 308-323

Odabasi AZ, Miles RD, Balaban MO, Portier KM 2007: Changes in brown eggshell color as the hen ages. Poult Sci 86: 356-363

Oloyo RA 2003: Effect of age on total lipid and cholesterol of hen eggs. Indian J Anim Sci 73: $94-96$

Peebles ED, Zumwalt CD, Doyle SM, Gerard PD, Latour MA, Boyle CR, Smith TW 2000: Effects of breeder age and dietary fat source and level on broiler hatching egg characteristics. Poult Sci 79: 698-704

Rizzi C, Chiericato GM 2005: Organic farming production. Effect of age on the productive yield and egg quality of hens of two commercial hybrid lines and two local breeds. Ital J Anim Sci 4: 160-162

Rossi M, Pompei C 1995: Changes in some egg components and analytical values due to hen age. Poult Sci 74: $152-160$

SAS Institute Inc. 2003: The SAS System for Windows. Release 9.1.3.

Silversides FG, Scott TA 2001: Effect of storage and layer age on quality of eggs from two lines of hens. Poult Sci 80: $1240-1245$

Suk YO, Park C 2001: Effect of breed and age of hens on the yolk to albumen ratio in two different genetic stocks. Poult Sci 80: $855-858$

Tůmová E, Ledvinka Z 2009: The effect of time of oviposition and age on egg weight, egg component weight and eggshell quality. Arch Geflügelkd 73 (in print)

Tůmová E, Skřivan M, Mandák K 1993: Technological value of eggs of Hisex Brown and D 29 laying hens. Sborník VŠZ v Praze, AF, řada B. 55: 245-251 (In Czech).

Tůmová E, Zita L, Hubený M, Skřivan M, Ledvinka Z 2007: The effect of oviposition time and genotype on egg quality characteristics in egg type hens. Czech J Anim Sci 52: 26-30

Van den Brand H, Parmentier HK, Kemp B 2004: Effects of housing system (outdoor vs. cages) and age of laying hens on egg characteristics. Br Poult Sci 45: 745-752

Vits A, Weitzenburger D, Hamann H, Distl O 2005: Production, egg quality, bone strength, claw length, and keel bone deformites of laying hens housed in furnished cages with different group sizes. Poult Sci 84: 1511-1519

Yannakopoulos AL, Tserveni-Gousi AS 1987: Effect of egg weight and shell quality on day-old duckling weight. Arch Geflügelkd 51: 157-159

Yannakopoulos AL, Tserveni-Gousi AS, Nikokyris P 1994: Egg composition as influenced by time of oviposition, egg weight, and age of hens. Arch Geflügelkd 58: 206-213

Zemková L, Simeonovová J, Lichovníková M, Somerlíková K 2007: The effects of housing systems and age of hens on the weight and cholesterol concentration of the egg. Czech J Anim Sci 52: 110-115

Zhang LC, Ning ZH, Xu GY, Hou ZC, Yang N 2005: Heritabilities and genetic and phenotypic correlations of egg quality traits in brown-egg dwarf layers. Poult Sci 84: 1209-1213 
